\title{
Iowa's First Banking System
}

\author{
By H. EARL Cook ${ }^{*}$
}

"It lived and operated to benefit and bless .... its record ought to be an inspiration and a benediction in the world of commerce, and its history, a beacon star in the firmament of honest financiering."

Thus was Iowa's first banking system described almost sixty years ago. The praise may seem a little excessive to modern ears, but it was well deserved.

The story of Iowa's first banking system constitutes one of the brightest pages in your state's history and I am confident that much of it is already known to you. For that reason I will today discuss several of the less familiar aspects of that history, making use of material which has been developed in the course of our research on the origins of Federal deposit insurance. This history contains a few lessons which may be applicable to the present, for certainly none of us can deny the importance of the events of earlier years, nor can we fail to learn when we study them.

The structure of Iowa's first banking system is of particular interest, for it was one which was peculiar to the 19th century. It consisted of a State Bank which did no banking and a group of branch banks which were not branches! Let me explain these apparent contradictions.

The State Bank of Iowa, as it was known, was established in 1858, with branches operating in the major towns and cities. However, "State Bank" was simply the collective title for the branch banks, just as the "national banking system" is the term used to refer to all national banks today. Each of the branch banks had its own capital, its own officers, and distributed earnings to its own stockholders. In effect, it was an inde-

* An address delivered by Mr. Cook, chairman of the Federal Deposit Insurance Corporation, Washington, D. C., before the annual convention of the Iowa Bankers Association, Des Moines, November 9, 1954. 
pendent bank which, when joined with its fellow branches, constituted the State Bank of Iowa.

There were other interesting features of this system, perhaps the most important of which was its insurance plan to provide protection for noteholders. Iowa was one of the six states which, before 1860, introduced a form of bank-obligation insurance to the American banking scene.

It was a form of insurance which would seem strange to us today, even though we can recognize certain similarities to Federal deposit insurance. For example, assessments were levied on the insured obligations, but they were paid in advance, before the bank could open for business, on the total of such obligations which were permitted the bank. Futhermore, the insurance fund built up by these assessments was not to be used to reimburse the insured creditors of failed banks but, rather, the other participating banks. This rather odd condidition existed because it was felt to be of paramount importance that insured obligations be paid immediately in event of bank failure. Consequently, when a bank failure occurred, the insurance plan provided that the supervisory authority levy upon the other participating banks for the cash necessary to reimburse noteholders, with the assessed banks to be reimbursed from the insurance fund.

\section{Federal Tax on Note Issue}

In all, there were fifteen banks in the first Iowa banking system, most of which operated from 1858 until 1865. The system was ended after this short life, not because of any dissatisfaction with its performance, but because a prohibitive Federal tax was levied on the notes of state banks. Note issue was then an important part of commercial banking, for at that time there were no treasury notes used as circulating medium, nor any central bank like the Federal Reserve to issue notes. There was nothing else for the Iowa banks to do but to take out national charters.

A look at several of the items in the combined state- 
ment of condition for the branch banks of the state of Iowa is of interest. Among the assets, gold and silver coin loomed large, constituting from 10 to 30 percent of total bank obligations. There was certainly no question of the inadequacy of reserves!

Capital was substantial. In fact, the ratio of capital to total assets ranged from 38 percent to a low of 19 percent. Liabilities consisted almost entirely of deposits and circulating notes, although it is interesting to observe that the amount of deposits was considerably larger than circulating notes for most of the period.

This prompts the question as to why insurance applied only to circulating notes since it meant that less than half of the bank obligations were insured. There were probably two reasons: First, it was felt that depositors did not require as much protection as noteholders, who were more frequently persons of modest means; second, it was not thoroughly understood that deposits as well as notes constituted a part of the circulating medium.

\section{INDEPENDENT BANKS AUTHORIZED}

Let me turn now from a description of the system to the history of its origin, for therein is an excellent illustration of the importance of ideas in banking. The story actually begins in 1834, when the State Bank of Indiana was established. Banking was prohibited in Indiana under its first constitution, except for a rather curious loophole which permitted the establishment of one bank, with branches. Evidently public opinion was opposed to a banking monopoly of this sort, so the legislature authorized the establishment of independent banks, but, to conform with the constitution, required that they be known as branch banks and that, collectively, they comprise the State Bank. The position of president of the State Bank was comparable to that of bank commissioner today, while its board of directors would be similar in authority to the banking Boards found in a number of states. Thus banking supervision was the only important function of the State Bank.

It was required of the Indiana banks that they be mu- 
tually liable not only for the notes, but also for the deposits of any failing bank. In part, because of this mutual guaranty, or insurance feature and, in part, because of the excellent supervision and management of the banks, the Indiana banking system soon became one of the soundest and strongest state banking systems in the country.

The scene now shifts to my native state, Ohio, which in 1845 , was attempting to reconstruct its banking system out of the wreckage of the deep depression of the early 1840 's. During that depression, when the notes of many Ohio banks circulated at depreciated values, those of the Indiana banks had passed at par. Consequently, the legislature provided for the establishment of a similar banking system in Ohio, going so far as to call each of the participating banks branch banks and vesting supervision in the State Bank.

Ohio retained the insurance feature of Indiana's law, but with some revisions. Even before Indiana adopted the principle of mutual guaranty, New York and Vermont had established insurance systems for depositors and noteholders which called for assessments on insured banks and the maintenance of an insurance fund. Although neither of these eastern systems had been quite as successful as that of Indiana, the idea of an insurance fund appealed to the Ohio legislature and was incorporated into the state's banking act of 1845 . Also, New York in 1842 had restricted insurance to noteholders and this was carried over into the Ohio act.

\section{First Bank In Iowa FaILed}

While this cross-fertilization of banking ideas was taking place, Iowa was moving in another direction in an attempt to solve its banking problems. When the first state constitution was adopted in 1846, the Miner's Bank of Dubuque had just failed. This was the first bank in Iowa, having been started in 1836, when Iowa was still a part of the Wisconsin Territory. Partly because of the fate of the Miner's Bank and partly because of the general prejudice toward banks which flourished 
in the West, the Iowa constitution treated the subject of banking on the following terms:

The General Assembly of this State shall prohibit, by law, any person or persons, association, company or corporation from exercising the privilege of banking or creating paper to circulate as money.

As you know, this prohibition of banking was not really effective; it merely led to the development of a thoroughly unworkable banking situation. In the first place, there was a substantial increase in the number of pri. vate banks. This was inevitable, since the rapid settlement and economic growth of Iowa prompted enterprising men to furnish the credit facilities which were so much in demand.

Many of these early private banks were excellently managed and some developed into quite substantial enterprises. Others were marginal concerns, appearing and disappearing as circumstances dictated. There is record, for example, of one bank so small that it was described as the place where the banker loaned, and took money in the front room and fried eggs for his dinner in the back room. And, of course, there were some private banks operated by men more interested in quick personal gain than in the building of a worthwhile business. The basic trouble was that, having prohibited regular banking, the state could not exercise effective supervision over those private banks which began to spring up.

\section{Private Banknotes Prohibited}

The existence of private banks did not solve a very important problem arising out of the constitutional prohibition I described earlier: that of providing a circulating medium. You will recall that it was not only unlawful to start a bank but also to issue banknotes, or anything similar to banknotes, which would serve as hand-to-hand currency. Since gold and silver coin was a scarce item in this recently settled area, and the deposit business of the private banks was very meager, something was needed for ordinary business transactions. The need was met in two ways: creation of so-called 
"Iowa-Nebraska" banks and the issuance of scrip by business firms.

The "Iowa-Nebraska" banks received their name from the fact that although they were chartered by the Nebraska Territory, they were organized to do business in Iowa. There were at least three such banks of this type, one of which perferred to do business under the rather misleading title of Western Exchange Fire and Marine Insurance Company. However, the circulating medium furnished by these banks did not meet the needs of the new state. As in the case of the private banks, lack of effective supervision resulted in unsound banking practices. In the Panic of 1857 all of the "Iowa-Nebraska" banks failed. How well they had been managed is suggested by the fact that when one such bank closed its doors during the panic, it is reported, and I quote: "its assets were thirteen sacks of flour, one iron safe, a counter desk, one stove drum, three arm chairs, and a map of Douglass county."

\section{Scrip Was Circulating Medium}

The issuance of scrip by business firms also provided the state of Iowa with a kind of circulating medium. Such scrip was designed to resemble banknotes and was used by the issuer to purchase farm produce with the hope-frequently ill-founded-that the scrip could be redeemed from the receipts of the sale of that produce. An example of this way of doing business in Davenport, Iowa, was given by a contemporary observer. $\mathrm{He}$ writes, "I have a very distinct recollection of seeing [this business man] carrying in his [high silk] hat whole printed sheets resembling bank bills ... and in his vest pocket a pair of scissors, so that whenever and whereever he was met on the street or other place, he was prepared to pay in this currency for wheat or pork or any other legal claims by simply extracting from his capacious hat a sheet of what he called money and with his scissors cutting off the necessary sum to liquidate the claim!"

As you can see, the prohibition of banking by the Iowa 
legislature turned out to be no solution at all to the banking problem. The result was that businessmen in the new state were forced to operate under severe handicaps and the currency was completely undependable in both quantity and quality. In fact, the banking situation had become so notorious by 1857 , that the new Iowa constitution adopted in that year permitted two types of banks: "free banks" and a State Bank with branches. Although both types of bank were authorized by the legislature in 1858, "free banks" were not established at this time, so that their characteristics need not detain us. However, the State Bank, a direct descendent of the Indiana and Ohio banks I described was established.

It was more than proximity to Indiana and Ohio which prompted Iowa to follow their example. Ralph Phillips Lowe, Governor of Iowa when the State Bank was established, was a former resident of Ohio. Futhermore, the key individual on the standing committee on banking in the Iowa senate when the act was passed was Samuel Jordan Kirkwood (later Iowa's war governor) a former Ohio resident who had taken an active interest in the State Bank of Ohio.

Thus, we see how Iowa came to have, as its first banking system, a State Bank which itself did no banking and branch banks which did the banking but were not branches, in the modern sense. This limited survey of the movement of banking ideas prompts me to raise an interesting question, one which is perhaps worthy of research by some member of your staff when he attends one of the graduate banking schools.

The president of the State Bank of Iowa was Hiram Price. The first man to introduce a bill in the United States congress for nationwide insurance of bank deposits was W. T. Price, a Republican representative from Wisconsin, in 1886. Both Hiram and W. T. Price originally came from Pennsylvania and the latter (Congressman Price) lived in Iowa for a short time before moving to Wisconsin. It would be interesting indeed if it could be discovered that there was a relationship, 
either by blood or friendship, between the two men, because we would then have the link between the early state insurance systems and the beginning of the movement in the Federal congress which eventually resulted in the passage of Federal deposit insurance legislation in 1933.

\section{EARLY BANKS OUTSTANDING}

Having considered the structure and origins of Iowa's first banking system, it is now appropriate to appraise its operating record. As the quotation with which I opened this talk indicated, it was truly an outstanding record for the period. The banks served their respective communities well, they were profitable, and there were no bank closings during the entire period of operations.

It is true that several banks became involved in financial difficulties, but in each instance discoverey by supervisory officials was so prompt and action so swift that closing was averted. In one case it appears that, through the insurance system, a deferred deposit was placed in a distressed bank. It might be noted that in 1950 congress gave the Federal Deposit Insurance Corporation the power to make subordinated deposits. Although this power has never been used by us, since it is only designed for exceptional cases, it is nevertheless interesting that almost a century ago some of our most modern insurance techniques were practiced.

Since no insured bank was closed, there was never any necessity for bringing into play those portions of the insurance plan having to do with the payment of insured obligations. Nevertheless, the very existence of insurance was an important factor in the successful operation of the system.

In the first place, confidence in individual banks, always a tremendously important element in banking stability, was possible of even greater significance at that time than in the present. Consider, therefore, how reassuring it must have been to customers of Iowa banks to know that the insurance fund was equal to 
about 21 percent of insured obligations and 8 percent of total obligations (notes and deposits). We will never know how many bank runs were averted because of the existence of this fund, just as we cannot adequately appraise today the benefits of the insurance fund under Federal deposit insurance. The nature of the relationship between banking confidence and an insurance fund is such that results are measured by events which do not occur rather than those which do.

\section{Insured Banks Carefully Examined}

Insurance of bank obligations in Iowa also brought more effective bank examination, for it was recognized that insurance could not succeed unless there was some control over the risk involved. As in Indiana and Ohio, supervisory authority was vested in the president and directors of the State Bank, with the latter consisting of one representative from each branch bank and three members elected by the state legislature. Under the law there were regular examinations and examiners had full access to bank records, procedures which are common today but were still novel in 1858 .

Because of the twin facts that each bank was represented on the supervisory board and each was liable to a special assessment in the event one of their members failed, supervision was exceedingly thorough. Each bank quite naturally sought to assure that the other banks were operating in a sound manner, since the failure of one affected all. This very justifiable concern for good supervision should provide some matter for thought, for the relationship between insurance and sound banking is fundamental.

It is true that, with more than 13,000 insured banks, it is not practical to have each bank individually represented on the board of the Federal Deposit Insurance Corporation. Nevertheless, the interests of each insured bank are effectively reflected in the corporation's continuing campaign to assure a high calibre of bank supervision. Just as it was clearly apparent to each Iowa bank that its future was closely allied with maintenance 
of a stable state banking system, so it should be apparent to you that when we press for better supervision in a state possibly far removed from Iowa, we are acting in your interests as well as those of the bankers of that state.

My account of your state's first banking system has been brief, as those of you who are acquainted with Iowa's banking history well know. Nevertheless, I hope that I have been able to bring to life a period in your banking history which is deserving of the study and approbation of all of us.

This history is worth reviewing because although one banking system may give way to another, sound banking principles live on. Through the years they are handed down from generation to generation. The principles which guided early Iowa banking are dominant today: insurance of bank obligations, effective supervision and sound bank mangement. Thus it is that Iowa can proudly claim a total of 665 banks with assets approaching three billion dollars.

It is interesting to compare this present situation with that which prevailed in the 1920's and early 1930's. Overbanking, which was reflected in the existence of more than 1,900 banks in 1920 , is no longer a problem. The failure rate, which was in excess of 100 Iowa banks per year, is but a dim memory. Since 1933, only 6 insured banks have become involved in financial difficulties sufficiently serious to warrant action by the Federal Deposit Insurance Corporation. The record during the past twenty years testifies to the achievement of Iowa bankers.

This is the kind of banking stability which all of us who have labored in banking have sought to attain. It is the kind of stability which your very first banking system attained. And I hope-indeed, I believe-that when future historians come to appraise the present Iowa banking system, they will be as impressed with your accomplishments as we all are today with those of Iowa's pioneer bankers. 
Copyright of Annals of Iowa is the property of State of Iowa, by \& through the State Historical Society of Iowa and its content may not be copied or emailed to multiple sites or posted to a listserv without the copyright holder's express written permission. However, users may print, download, or email articles for individual use. 